\title{
ASO Visual Abstract: PET Imaging and Rate of Pathologic Complete Response in Esophageal Squamous Cell Carcinoma
}

\author{
M. Hart Squires, $\mathbf{M D}^{\mathbf{1}}$, Nicole Gower, BS ${ }^{1}$, Jennifer H. Benbow, $\mathbf{P h D}^{1}$, Erin E. Donahue, $\mathbf{P h D}^{\mathbf{1}}$, \\ Casey E. Bohl, MD, $\mathrm{PhD}^{2}$, Roshan S. Prabhu, $\mathrm{MD}^{3}$, Joshua S. Hill, MS, MD', and Jonathan C. Salo, MD, FACS ${ }^{1}$ (D) \\ ${ }^{1}$ Levine Cancer Institute, Atrium Health, Charlotte, NC; ${ }^{2}$ Atrium Health, Charlotte, NC; ${ }^{3}$ Southeast Radiation Oncology \\ Group, Carolinas Medical Center, Levine Cancer Institute, Atrium Health, Charlotte, NC
}

For patients with esophageal squamous cell carcinoma with a clinical response to chemoradiation, a strategy of active surveillance has been proposed. We show that positron emission tomography (PET) is a poor predictor of who will experience a pathologic complete response to chemoradiation (https://doi.org/10.1245/s10434-021-1064 $4-4)$.

Publisher's Note Springer Nature remains neutral with regard to jurisdictional claims in published maps and institutional affiliations.

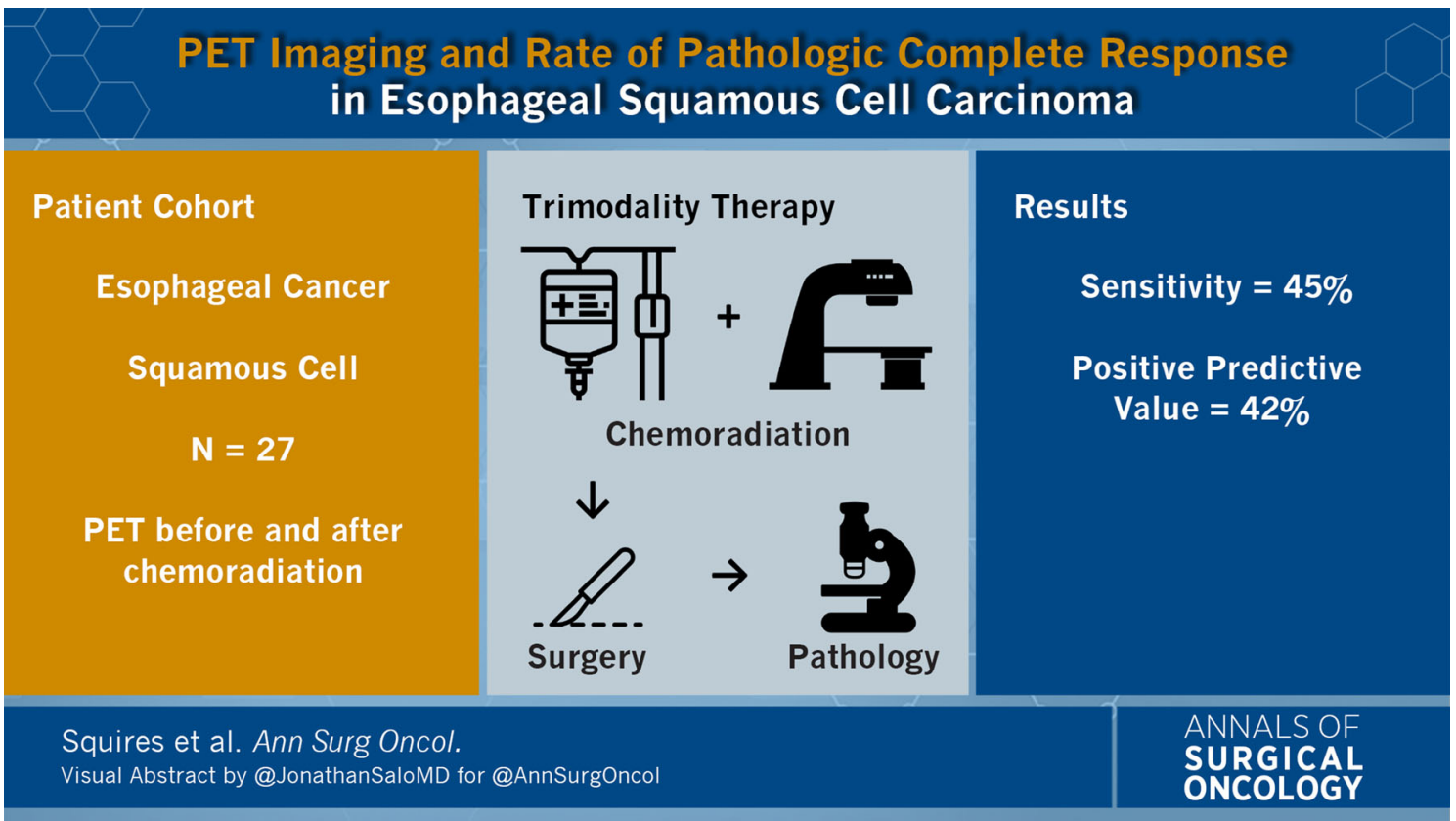

(C) Society of Surgical Oncology 2021

Published Online: 21 September 2021

J. C. Salo, MD, FACS

e-mail: Jonathan.salo@atriumhealth.org 